\title{
Correspondence
}

https://doi.org/10.11646/megataxa.1.1.12

\section{Old and new challenges in taxonomy: what are taxonomists up against?}

\author{
NADINE DUPÉRRÉ 1 \\ ${ }^{1}$ Zoological Museum, Center of Natural History, Universität Hamburg, Martin-Luther-King-Platz 3, 20146 Hamburg, Germany. \\ झ"Nadine.duperre@uni-hamburg.de; ㄴhttps://orcid.org/0000-0003-2195-878X
}

\section{How is alpha taxonomy coping with Natural History Museum staff and funding shortages?}

Taxonomy is undeniably attached to natural history museums as they provide repositories for type specimens, historical specimens, as well as time series vouchers. As such, museums are the safeguard of the earth's biodiversity, with an estimated 3 billion objects stored in museums worldwide (Wheeler et al. 2012). The worldwide lack of funding and staff cutbacks in natural history museums is nothing new. Since 1988, examples of natural history museum cutbacks have been reported from all over the world: in Europe-the British Museum of Natural History (Bourne 1988) and numerous Italian natural history museums (Andreone et al. 2014); in North America-the Field Museum in Chicago (Shen, 2012) and the generalized "funding freeze" in the USA (Yong, 2016); and in South America-in Brazil, while the Instituto Butantan and Brazil National Museum represent wellknown examples, other smaller museums have suffered the same cutbacks/consequences or even completely closed their doors. Laskow (2017) reported that "across North America, more than 100 herbaria have closed in the past 20 years and in the UK, about 64 museums, but not all of those were natural history museums". This is also true for Italian museums such as the Friulian Museum of Natural History that has been closed since 1998 and the Turin Museum of Natural History that was closed after an accidental explosion in 2013 (Andreone et al. 2014).

No one will oppose the idea that funding of Natural History Museums is essential in order to keep collections available to researchers, to maintain specimens in good condition for long-term preservation, and to provide data via substantial databases. Funding cutbacks have affected NHMs in myriad ways: difficult or no physical access to collections; reduced staff to curate, preserve or loan specimens; reduced number of curators and taxonomists to study the millions of undiscovered and unidentified species; reduced or no access to data (images of specimens, locality data).

\section{How are these cutbacks and their negative impacts affecting taxonomists and taxonomy?}

First, little or no physical access to type specimens for research is a major drawback to taxonomical studies. One could argue that digitization of type specimens can solve this problem, but digitization, more than often is inadequate; images are either too low in resolution, of poor quality, or the diagnostic characters are not being presented comprehensibly or generally the specimens have not been digitized. If specialists do not have access to crucial specimens such as type or vouchers, research quality is indubitably lowered. Most museums still send and loan type material, but the policies of none-shipping type material for safety reasons is growing, especially if the request comes from less stable countries. Of course, there is always a risk in sending specimens by mail, but this risk is outweighed by the scientific benefits and the right of taxonomists to examine the type specimens of their countries. How can taxonomists in South America, Asia or Africa work on their continent's fauna when most of the early types $(<1900 s)$ are stored in European museums and more recent types (1900s) are stored in US collections? Travelling to all those museums when conducting a taxonomical revision is impossible, due to expenses and time consumption. As such, taxonomists are therefore faced with an impossible task and often discouraged to tackle taxonomic questions, or they have no choice but to publish without examining type specimens, vouchers or historical specimens which can negatively affect the taxonomy of a group rather than clarify it with the duplication of scientific names and taxonomic instability.

Second, the reduction of technicians, curatorial staff and curators in museums worldwide is very concerning for the future of taxonomy and biodiversity research, as type specimens, vouchers or historical specimens are not being efficiently cared for. Safety of the specimens is impaired and accidents have happened, such as in the Turin Museum in Italy and the Brazilian Museums, where lack of funding and demands for renewed investment in 
renovations, security, and protection have been ignored for decades (Zamudio et al., 2018). The decline in funding for NHMs directly affects taxonomy by: reducing the meticulousness of taxonomic publication; prolonging species descriptions; increasing travel costs; decreasing access to specimens and data. All of these outcomes create an extensive bottleneck to taxonomic research and a cascading effect to other fields of study.

2. Is alpha taxonomy being falsely portrayed as: the tedious, painstaking, time-consuming labour, the none-accessible, old-fashioned science?

The campaign to discredit alpha taxonomy as an effective, modern, valid science is not new.

Frequently taxonomy is directly or indirectly undermined, and negatively portrayed, not only can it be observed in scientific publications but also on internet websites and word-of-mouth (e.g. Marshall 2005; Herbert et al. 2002; Matthew 2010; Carew et al. 2013; Zimmerman et al. 2015; Beng et al. 2016). Undoubtedly this attitude presents a false portrait of alpha taxonomy as today we conduct integrative taxonomy, utilizing many specimens, several types of data and multiple analyses, such as: traditional morphology, ecological and behavioral data, image stacking software, micro-CT scanning, and scanning electron microscopy. Fortunately, many researchers have risen up to endorse taxonomy, and one would hope that the era of taxonomic justification is over, and the era of taxonomic destigmatization has begun.

\section{How will taxonomists face the trend of naming species based on DNA without morphological diagnosis or description?}

In 2016, Renner reported that 98 species had been described and named solely with DNA-based diagnostic characters, with or without additional morphological characters. Of these, 19 species have been named without any morphological diagnoses or descriptions (6 species of lichens, 3 species fungi and 10 species of lepidoptera). This means that no one-no taxonomist, no ecologist, no conservation biologist-nobody on the planet can somatically recognize at least 19 species.

Renner (2016) commented that "DNA-based diagnoses along with (generously loaned) museum specimens and stably archived specimen images to my mind are more important today than attempts to "cover" morphological variation in populations...."

The first issue with this statement is that museum specimens are not "generously" loaned, in fact the cost of preparing and shipping type specimens is not negligible, furthermore new museum policies have emerged in which museum tend to avoid shipping type specimens either for the safety of the specimens or lack of staff. The delay to received museum specimens can vary greatly, from a few weeks to years. As a result, researchers need to travel to various museums at very high cost to examine type material or wait quite some time to received material.

The argument that stably archived specimen images will also enable identification is also a fictive argument. As taxonomists we appreciate well-imaged specimens, but in most cases the important morphological characters are not imaged well enough, or the specimens require dissection for accurate identification, as such the reexamination of type specimens is more than often necessary. Unless more resources are made available, the comprehensive digitization of specimens is a noble but unrealistic endeavour, the practice is time-consuming and costly, and museums simply lack the staff and taxonomic expertise to accomplish this immense task.

The main argument to DNA diagnosis and description rather than morphological diagnosis and description for naming species is that it will "speed up" the description process at a "lower cost" (Riedel et al. 2013; Renner 2016). Perhaps it could speed up the process of naming species, but at what scientific cost? DNA based diagnoses and descriptions will significantly slow down or render impossible identification of historical museum specimens, it will impair science in developing countries by creating barriers to efficiently identify and describe their own biodiversity (due to high cost, lack of staff, and technology), consequently undermining other fields of study (conservation, ecology, biodiversity), and will undoubtedly impoverish the scientific community of crucial morphological, behavioural or ecological data.

Morphological, behavioural or ecological data presented in taxonomic work is consequential. For example, the concept of character displacement (Brown \& Wilson, 1956) arose in part from taxonomic patterns that Wilson observed in his Lasius taxonomic revision (Ward 2007). In his revision, Wilson (1955) gave considerable attention to biological traits (including nesting behavior, foraging habits, and habitat preferences) that eventually gave rise to this influential concept.

Indeed, providing a diagnosis in the process of naming a new species is often the most difficult part of species description. Some closely related species show no or little morphological differences. For this reason, it is essential that a diagnosis be written with a combination of characters (morphological, ecological, behavioural and genetic) in order to separate species and to validate its identity. To add a DNA character to the description or diagnosis is one tool among many, but not a functional replacement. However, species named and described without a discrete set of characters is a step down in 
science, going back to an age of species naming with one sentence or one word (Stearn 1992). Earlier taxonomists described species with only a few words often without any illustrations. At that time, they probably thought that they provided enough characters to distinguish species, but as taxonomists know, the heritage that left us includes the impossibility of identifying many species and the obligation to re-examine and re-describe type material. We want to avoid past mistakes by not trimming down species descriptions and diagnoses to one DNA sequence and leave future researchers with taxonomic chaos.

The ICZN article 13.1.1. states that to be available, a new species name published after 1930 "must be accompanied by a description or definition that states in words characters that are purported to differentiate the taxon" (ICZN 2019). However, interpretation of the code differs amongst researchers, and article 13 has been broadly interpreted or ignored by some researchers (Cifelli \& Kilean-Jaworowska 2005). Can a DNA sequence be considered as a character that differentiates a taxon if it is stated in words? (e.g.--"by the following combination of character states of the DNA barcode: 121T; 123C; $298 \mathrm{~T}$ (Brower 2000")). The ICZN should clarify article 13 to avoid broad interpretation and formalize its position on the use of DNA sequences in descriptions and diagnoses of new species, as well as on the validity of species described solely from molecular characters.

Let us not forget that DNA sequencing is not incontestable and that mistakes can occur. As stated by Buhay (2009) "it is commonplace to question identification of species by zoologists as a source of error in phylogenetic studies, but as this study has shown, molecular data errors are not just negligible issues anymore - they are cause for serious concern which must be addressed". Mistakes can occur at many levels: contamination, presence of numts, manual editing errors or sequencing errors that contribute to erroneous data that can confound genetic analysis (Potapov \& Ong 2017). In fact, it was shown that some markers (cox1) can potentially overestimate biodiversity (Lopardo \& Uhl 2014) and that past introgression and interbreeding apparent in COI are a source of major genetic problems (e.g. Cong et al. 2000).

Last but not least, Riedel et al. (2013) argued that: "we strongly believe that the ICZN should make the publication of genetic data obligatory". I argue that to make the publication of genetic data obligatory for the validity of a new species description would be an act of unbelievable selfishness and egocentrism from more wealthy countries where DNA sequencing is affordable.

Though it may be cheap and easy in developed countries, the developing countries often do not have the money, the infrastructures or the staff to extract, analyze and produce DNA sequences. The obligation for researchers, curators, and taxonomists around the world to provide DNA sequences in species description will render species description impossible for less technically advanced countries, and the cost for DNA-based identification would be colossal for developing countries compare to their research budget. Let us not forget that biodiversity hotspots and the unknown biodiversity left to discover on the planet occur in those countries.

As stated by Pinheiro et al. (2019) "species identified by DNA barcode will likely just add to the already massive backlog". Species diagnosis and description based only on DNA will not only render identification impossible without seeing the type specimens, it will in fact increase cost and time. To truly expedite the taxonomical process in a scientifically valid way and not just for the sake of acceleration, species description and diagnosis should continue to be improved by modern methods while still incorporating a combination of characters (morphological, ecological, behavioural, genetic, etc).

\section{References}

Andreone F., Bartolozzi, L., Boana, G., Boero, F. Bologna, M.A., Bon, M., Bressi, N., Capula, M., Casala, A., Casiraghi, M. Chiozzi, G., Delfino, M., Doria, G., Durante, A., Ferrari, M., Gippoliti, S., Lanzinger, M., Latella, L., Maio, N., Mrangoni, C., Mazzotti, S., Minelli, A., Muscio, G., Nicolosi, P., Pievani, T., Razzetti, E., Sabella, G., Valle, M., Vomero, V. \& Zilli, A. (2014) Italian natural history museums on the verge of collapse ? Zookeys, 456, 139-146. https://doi.org/10.3897/zookeys.456.8862

Beng, K.C., Tomlinson, K.W., Shen, X.H., Surget-Groba, Y., Hugher, A.C., Corlett, R.T. \& Slik, J.W.F. (2016) The utility of DNA metabarcoding for studying the response of arthropod diversity and composition to land-use change in the tropics. Nature, Scientific reports, 6 (24965), 1-13. https://doi.org/10.1038/srep24965

Brown, W.L., Jr. \& Wilson E.O. (1956) Character displacement. Systematic Zoology, 5, 49-64.

Bourne, W.R.P. (1988) Cuts at the British Museum (NH). Nature, vol. 333, 26 May 1988, p. 292.

Buhay, J.E. (2009) "COI-LIKE" sequences are becoming problematic in molecular systematic and DNA Barcoding studies. Journal of crustacean biology, 29 (1), 96-110. https://doi.org/10.1651/08-3020.1

Carew M.A., Pettigrove, V.J., Metzeling \& Hoffmann, A.A.L. (2013) Environmental monitoring using next generation sequencing: rapid identification of macroinvertebrate bioindicatot species. Frontiers in Zoology, 10 (1) 45, 1-15. https://doi.org/10.1186/1742-9994-10-45

Cifelli, R.L. \& Kilean-Jaworowska, Z. (2005) Diagnosis: Differing interpretations of the ICZN. Acta Palaeontological Polonica, $50(3), 650-652$.

Cong, Q., Shen, J., Borek, D., Robbins, R.K., Opler, P.A., Otwinowski, Z., \& Grishin, N.V. (2017) When CO1 barcodes deceive: complete genomes reveal introgression in hairstreaks. Proceeding of the Royal Society, B, 284, 20161735, 1-9. http://dx.doi.org/10.1098/rspb.2016.1735

Dalton, R. (2003) Natural history collections in crisis as funding is 
slashed. Nature, 423, 575.

https://doi.org/10.1038/423575a

Herbert, P.D.N., Cywinska A., Shelley L. Ball \& de Waard J.R. (2003) Biological identifications through DNA barcodes. Proceedings of the royal society $B, 270,1512,313-321$. https://doi.org/10.1098/rspb.2002.2218

ICZN (2019) International Commission on Zoological Nomenclature. International Code of Zoological Nomenclature. Available from: https://www.iczn.org/thecode/the-international-code-of-zoological-nomenclature/thecode-online/ (Accessed 30 December 2019)

Laskow, S. (2017) It's Hard to Be a Natural History Museum in the 21 st Century. As belts tighten, rich collections of plant and animal specimens face relegation, dissolution, or worse. Available from: https://www.atlasobscura.com/articles/ natural-history-museums-closing-survival-modernizing (Accessed 1 December 2019)

Lopardo, L. \& Uhl, G. (2014) Testing mitochondrial marker efficacy for DNA barcoding in spiders: attest case using the dwarf spider genus Oedothorax (Araneae: Linyphiidae: Erigoninae). Invertebrate Systematics, 28, 501-521. http://dx.doi.org/10.1071/IS14017

Marshall, E. (2005) Will DNA Bar Codes Breathe Life into Classification? Science, 307, 1037. https://doi.org/10.1126/science.307.5712.1037

Matthew, H.D. (2010) Alpha taxonomy — a dead science? Available from: https://www.sci.hokudai.ac.jp/ mhdick/dick/page3/ page3.html (Accessed 12 January 2020).

Potapov, V. \& Ong, J.L. (2017) Correction: Examining Sources of Error in PCR by Single-Molecule Sequencing. PLOS ONE $12,7, \mathrm{e} 0181128$. https://doi.org/10.1371/journal.pone.0181128

Pinheiro, H.T., Moreau, C.S, Daly, M. \& Rocha, L.A. (2019) Will DNA barcoding meet taxonomic needs? Science, 365 (6456), 873-874.

https://doi.org/10.1126/science.aay7174

Renner, S.S. (2016) A Return to Linnaeus's Focus on Diagnosis, Not Description the use of DNA characters in the formal naming of species. Systematics Biology, 65, 6, 1085-1095. https://doi.org/10.1093/sysbio/syw032

Riedel, A., Sagata K., Suhardjono Y.K., Tänzler, R. \& Balke, M. (2013) Integrative taxonomy on fast track -towards more sustainability in biodiversity research. Frontiers in Zoology 2013, 10-15. https://doi.org/10.1186/1742-9994-10-15

Shen, H. (2012) Nature.com. Chicago's Field Museum cuts back on science. Available from: https://www.nature.com/news/ chicago-s-field-museum-cuts-back-on-science-1.12105 (Access 1 December 2019).

https://doi.org/10.1038/nature.2012.12105

Stearn, W.T. (1992) Botanical Latin: history, grammar, syntax, terminology and vocabulary. 4th ed., Timber Press, Portland, Oregon, $546 \mathrm{pp}$.

Ward, P.S. (2007) Edward O. Wilson and his contributions to ant systematics. In: Snelling, R. R., B. L. Fisher, and P. S. Ward (Eds), Advances in ant systematics (Hymenoptera: Formicidae): homage to E. O. Wilson-50 years of contributions. Memoirs of the American Entomological Institute, Philadelphia, 80, pp. 3-7.

Wheeler, Q.D., Knapp, S., Stevenson, D.W., Stevenson, J., Blum, S.D., Boom, B.M, Borisy, G.G., Buizer, J.L., De Carvalho, M.R., Cibrian, A., Donoghue, M.J., Doyle, V., Gerson, E.M., Graham, C.H., Graves, P., Graves, S.J., Guralnick, R.P., Hamilton, A.L., Hanken, J., Law, W., Lipscomb, D.L., Lovejoy, T.E., Miller, H., Miller, J.S., Naeem, S., Novacek, M.J., Page, L.M., Platnick, N.I., Porter-Morgan, H., Raven, P.H., Solis, M.A., Valdecasas, A.G., Van Der Leeuw, S., Vasco, A., Vermeulen, N., Vogel, J., Walls, L., Wilson, E.O., Woolley, J.B. (2012) Mapping the biosphere: exploring species to understand the origin, organization and sustainability of biodiversity. Systematics and Biodiversity, 10, 1-20. https://doi.org/10.1080/14772000.2012.665095

Wilson, E.O. (1955) A monographic revision of the ant genus Lasius. Bulletin of the Museum of Comparative Zoology, 113, $1-201$.

Yong, E. (2016) The Atlantic. Funding Freeze Hits Natural History Museum Collections. Available from: https://www.theatlantic. com/science/archive/2016/03/funding-freeze-hits-naturalhistory-museum-collections/474981/ (Accessed 1 December 2019).

Zamudio, K.R., Kellner, A., Serejo, C., Ribero de Britto, M., Castro, C.B., Buckup P.A., Pires, D.O., Couri, M., Brilhante Kury, A., Azevedo Cardoso, I., Monné, M.L., Pombal Jr., J., Mello Patiu, C., Padula, V., Dias Piementa, A., Rezende Ventura, C.R., Hajdu, E., Zanol, J., Bruna, E.M., Fitzpatrick J. \& Rocha, L.A. (2018) Lack of science supports fails Brazil. Science 361, 1322. https://doi.org/10.1126/science.aav3296

Zimmerman, J., Glöcjner, G., Jahn, R., Enke, N. \& Gemeinholzer, B. (2015) Metabarcoding vs. morphological identification to assess diatom diversity in environmental studies. Molecular Ecology Resources 15, 526-542. https://doi.org/10.1111/1755-0998.12336 